\title{
The economic impact of drying off cows with a dry-off facilitator (cabergoline) compared with 2 methods of gradual cessation of lactation for European dairy farms
}

\author{
W. Steeneveld, ${ }^{1 *}$ A. De Prado-Taranilla, ${ }^{2}$ K. Krogh,${ }^{2}$ and H. Hogeveen ${ }^{1,3}$ \\ ${ }^{1}$ Department of Farm Animal Health, Faculty of Veterinary Medicine, Utrecht University, Yalelaan 7, 3584 CL Utrecht, the Netherlands \\ ${ }^{2}$ Ceva Santé Animale, 10 Avenue de la Ballastière, 33500 Libourne, France \\ ${ }^{3}$ Chair, Business Economics Group, Wageningen University, Hollandseweg 1, 6706 KN Wageningen, the Netherlands
}

\section{ABSTRACT}

An abrupt method to dry off cows has disadvantages and is considered inappropriate for current dairy cows due to welfare issues and risks for intramammary infections (IMI). A gradual cessation of lactation (by feeding or milking frequency reduction) has been the generally recommended method for drying off cows to prevent these adverse effects. However, a new alternative to the gradual approach is to abruptly stop milking at the same time as using cabergoline (CAB), a prolactin inhibitor. The aim of the study was to compare the net costs of 3 different methods of drying off cows [gradual reduction in feed (referred to as gradual feeding), gradual reduction in milking frequency (referred to as gradual milking), and abrupt cessation of milking with CAB]. A stochastic Monte Carlo simulation model, at cow level, was developed to calculate the net costs of applying these methods. All inputs for the model were based on literature information, authors' expertise, and expert knowledge. The net costs were determined by only including costs and benefits, which varied between the 3 methods. The model simulated a cow from $7 \mathrm{~d}$ before the day of drying off until the end of the next lactation. The likelihood of whether a cow was leaking milk early in the dry period was determined. Subsequently, it was determined whether or not the cow will get an IMI during the dry period, where the probability of getting an IMI was higher for cows leaking milk than for cows not leaking milk. If the IMI was not cured during the dry period, the cow had an IMI at calving. Also, milk production and feed requirements were modeled, and labor for applying the drying off method was included. For all methods, the net costs were calculated as the sum of costs for feed during the gradual feed reduction period, costs for applying the gradual-milking method,

Received November 28, 2018.

Accepted April 13, 2019.

*Corresponding author: w.steeneveld@uu.nl and the IMI costs during the dry period and lactation, minus the milk revenues during the transition from lactation to the dry period. Under default conditions, the average net cost of abrupt cessation of milking with $\mathrm{CAB}$ was $€ 49.6 /$ cow. The data showed that $90 \%$ of the net costs ranged from $-€ 13.7$ to $€ 307.8 /$ cow. The average net costs for gradual feeding and gradual milking were $€ 99.1$ and $€ 71.5 /$ cow, respectively. In conclusion, abrupt cessation of milking with CAB saved $€ 49.5$ and $€ 21.9 /$ cow on average compared with gradual feeding and gradual milking, respectively. This difference was mainly due to more milk returns and lower labor and IMI costs during lactation.

Key words: dairy cow, drying off, cabergoline, intramammary infection, economics

\section{INTRODUCTION}

The dry period allows time for mammary tissues to recover and repair. Moreover, by using an antibiotic treatment at the moment of dry-off, there is a chance that existing infections can be cured. Milk yields per cow per year greatly increased in recent decades in both the United States (Zobel et al., 2015) and Europe (e.g., CRV, 2017). Consequently, milk yields at dry off have also increased considerably from 9 (Natzke et al., 1975) to 12 to $30 \mathrm{~kg} / \mathrm{d}$ in Europe (Steeneveld et al., 2013; Vilar et al., 2018) and to 24 to $30 \mathrm{~kg} / \mathrm{d}$ in North America (Annen et al., 2004; Chapinal et al., 2014).

Several methods are used to dry off cows that can be divided into 2 main groups: gradual drying off, when there is an intention to reduce the milk production before the dry-off through feeding or milking reduction (or both), and abrupt drying off in case this does not happen. An abrupt cessation of milking has previously been applied in some countries (Dingwell et al., 2004) and is also still applied (Bertulat et al., 2015). However, this method has several disadvantages, namely that it results in a high udder pressure and elevated stress levels (Bertulat et al., 2013), and that the excessive accumulation of milk at the time of dry off may lead to 
milk leakage (ML; Dingwell et al., 2004). Milk leakage and a high milk yield at dry off are risk factors for IMI established during the dry period (Klaas et al., 2005; Rajala-Schultz et al., 2005; Gott et al., 2016). Based on these disadvantages, abrupt cessation of milking is not recommended for cows producing more than $15 \mathrm{~kg} / \mathrm{d}$ at dry off (NMC, 2006; Zobel et al., 2013).

There are some alternatives to abruptly drying off high-producing cows. It has been recommended to stop concentrate feeding $2 \mathrm{wk}$ before the anticipated dry off (referred to as gradual feeding) for cows producing more than $15 \mathrm{~kg} / \mathrm{d}$ and thus to end up with a milk production at dry off below $15 \mathrm{~kg} / \mathrm{d}$ (NMC, 2006). A recent study reported that cows were dried off gradually in $96 \%$ of the farms, and that the ration was changed and feed intake restricted before the dry period in $87 \%$ of the farms (Vilar et al., 2018). However, this approach has been linked to cows experiencing hunger (Valizaheh et al., 2008; Tucker et al., 2009;), demonstrating signs of stress (Odensten et al., 2007a,b), and creating a temporary state of negative energy balance that may lead to metabolic problems (Odensten et al., 2005). National Mastitis Council (NMC, 2006) recommendations also mention that milking once per day (referred to as gradual milking) could be used as a method to achieve the target yield. Less ML was found in cows with these gradual methods in comparison with cows that were dried off abruptly (Zobel et al., 2013).

An alternative method to facilitate dry off is to induce a decrease in milk yield by reducing galactopoietic hormones in the blood, such as prolactin (Bach et al., 2015; Lacasse et al., 2016; Bertulat et al., 2017). For example, cabergoline $(\mathbf{C A B})$, a dopamine $\mathrm{D}_{2}$ receptor agonist, is a prolactin-release inhibitor at the level of the pituitary gland and a single injection of $\mathrm{CAB}$ at abrupt dry off (referred to as abrupt CAB) reduced blood prolactin concentrations for up to $8 \mathrm{~d}$ (Boutinaud et al., 2016). As a result, applying CAB at dry off reduced ML, udder pressure, and signs of udder pain (Bach et al., 2015; Bertulat et al., 2017). Less ML and faster mammary gland involution (Boutinaud et al., 2016, 2017) may result in less IMI.

Gradual reduction of milking results in fewer milk returns. Recently, a 33\% lower milk yield during the final week of lactation was found for such cows compared with those where abrupt cessations of milking was used (Gott et al., 2016). When applying a gradual method, the labor costs will increase as the farmer must apply an individual cow approach to lower the milk production of the cow. When applying gradual feeding, the feed costs will decrease due to a lower energy-dense ration (e.g., another ration), and when applying gradual milking the feed costs will decrease because less concentrates are used (e.g., during the once per day milking).
When using the abrupt-CAB method, the labor costs will be low, but the CAB injection has a cost. The IMI costs will also be influenced because of less ML.

No study has so far determined the economic differences between applying a gradual method to dry-off cows (by either feeding or milking frequency reduction) versus an abrupt method with a CAB injection. The aim was to compare the net costs of 3 different methods of drying off cows (gradual feeding, gradual milking, and abrupt $\mathrm{CAB})$.

\section{MATERIALS AND METHODS}

\section{Model Development}

A stochastic Monte Carlo simulation model at the level of the cow was developed to calculate the net costs of 3 different methods of drying off cows (gradual feeding, gradual milking, and abrupt CAB; Velactis, Ceva Sante Animale). The net costs were determined by only including costs and benefits, which varied between the 3 methods. These costs and benefits include feed costs during the milk reduction period, labor costs for applying the dry-off method, costs for applying the dryoff method (e.g., cost of CAB, costs for extra animal segregation fences), IMI costs during the dry period and the subsequent lactation, and milk revenues during the milk reduction period before the dry off. The model was developed using Microsoft Excel (Microsoft Corp., Redmond, WA) with @Risk add-in software (2002; Palisade Corp., Newfield, NY). All discrete events and variability with regard to the 3 different dry-off methods were triggered stochastically using random numbers drawn from relevant distributions. These distributions were based on knowledge of the model domain, information from the literature, and if no other information was available, on expert assumptions made by the authors. Input values and sources of information are presented in Tables 1 and 2. Model outcomes were generated in 2 steps. Every one of the 10,000 iterations during the simulation process simulated the cow events around drying off, related to the ultimate cessation of milk production. A total of 10,000 iterations were used to ascertain stable results on the economic outcomes. For each simulation, the net costs of the milk dry-off method were calculated. The model was run 3 times, once for each dry-off method.

\section{Simulation of a Cow}

The model simulated a cow from $7 \mathrm{~d}$ before the day of drying off until the end of the next lactation, assuming freestall housing and a TMR. Therefore, 2 consecutive lactations were modeled in daily time steps. First, 
Table 1. Input data on probability of milk leakage (ML), probability of IMI, and the dynamics of an IMI infection for gradual feeding, gradual milking, and abrupt cessation of milking with cabergoline (CAB)

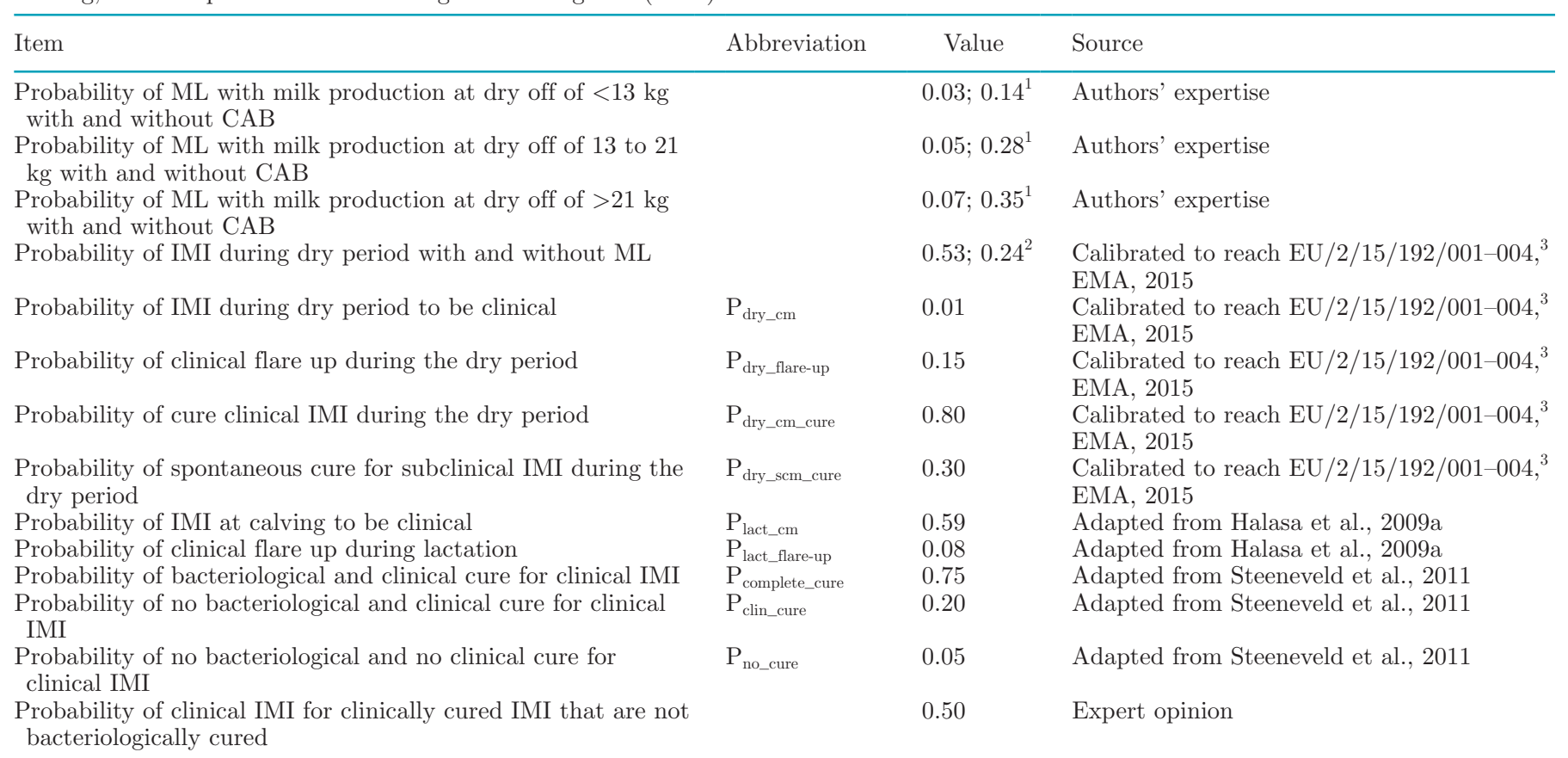

${ }^{1}$ Difference between with and without CAB based on an $81 \%$ reduction in ML with CAB (EMA, 2015).

${ }^{2}$ Difference between with and without ML based on an odds ratio of 2.2 of getting IMI with ML.

${ }^{3}$ Difference in probability of IMI at calving between abrupt cessation and CAB of $21 \%$.

cow parity was determined using a discrete distribution with possible values of $1(P=0.32), 2(P=0.25), 3(P$ $=0.18), 4(P=0.11)$, or $5(P=0.14$; Inchaisri et al., 2010). Subsequently, the calving interval of the cow was determined with a pert distribution with a minimum value of $336 \mathrm{~d}$, a most likely value of $410 \mathrm{~d}$ and a maximum of $556 \mathrm{~d}$. The length of lactation was determined by the calving interval duration less $60 \mathrm{~d}$. The 305-d milk production of a cow was determined by using a normal distribution with a mean of $10,000 \mathrm{~kg}$ and SD of $500 \mathrm{~kg}$. The $305-\mathrm{d}$ milk production of the subsequent lactation was based on the 305-d milk production of the previous lactation (from parity 1 to 2 : $14 \%$ increase, from parity 2 to $3: 8 \%$ increase, from parity 3 to $4: 1 \%$ increase, and from parity 4 to 5: $2 \%$ decrease; CRV, 2017). Daily milk production during both lactations were estimated using Wood's lactation curve (Wood, 1967). Based on a results of a trial it was assumed that there is no difference in milk production in subsequent lactation between gradual-feeding, gradual-milking, and abrupt-CAB treatments (unpublished data). Based on the milk production of the cow, the relative feed requirements were determined (Remmelink et al., 2017). Feed requirements were expressed as energy requirements using feed units for lactation (VEM; 1 VEM = $1.65 \mathrm{kcal}$ of $\mathrm{NE}_{\mathrm{L}}$ ) as defined by van Es (1978).
Using a discrete distribution, it was determined whether or not a cow had ML during the beginning of the dry period. The probability of ML was dependent on the milk production at dry off and whether $\mathrm{CAB}$ was used (Table 1). It was assumed that using $\mathrm{CAB}$ resulted in an $81 \%$ reduction in ML (EMA, 2015). Subsequently, it was also determined whether the cow will get an IMI during the dry period, and the probability of getting an IMI was higher for cows with ML $(P=0.53)$ than for cows without ML $(P=0.24$; Table 1$)$. When a cow gets an IMI during the dry period, the dynamics of this infection were simulated following the scheme in Figure 1 and the probabilities in Table 1 . Input values on the dynamics of infection were based on available literature, authors' expertise, and if needed, supplementary estimates. For instance, it was known that the difference in IMI at calving between abrupt cessation of milking and abrupt cessation of milking along with CAB was 21\% (EU/2/15/192/001-004; EMA, 2015); therefore, some input values were calibrated so that this difference was reached. For the purpose of the study, it was assumed that IMI are caused by environmental pathogens because the infection starts during the dry period and during that period it is less likely that IMI are caused by contagious pathogens. When cows were not cured during the dry period, the cows had an IMI 
Table 2. Values and source of parameters used in the simulation model

\begin{tabular}{|c|c|c|}
\hline Variable & Value & Source \\
\hline \multicolumn{3}{|l|}{ IMI } \\
\hline Cost of medicines for $\mathrm{CM}^{1}(€)$ & 22 & van Soest et al., 2016 \\
\hline Probability of veterinary visit for CM (\%) & 5 & van Soest et al., 2016 \\
\hline Cost of veterinary visits for $\mathrm{CM}(€ /$ visit $)$ & 22 & van Soest et al., 2016 \\
\hline Withdrawal period for CM $(\mathrm{d})$ & 6 & van Soest et al., 2016 \\
\hline Treatment time for CM during dry period (min) & 60 & Authors' expertise \\
\hline Treatment time for CM during lactation (min) & 45 & van Soest et al., 2016 \\
\hline Production losses for clinical IMI at calving (\%) & 8 & Huijps et al., 2008 \\
\hline Production losses for clinical flare-up (\%) & 5 & Huijps et al., 2008 \\
\hline Cost of production losses $(€ / \mathrm{kg})$ & 0.35 & Blanken et al., 2018 \\
\hline Average duration of subclinical IMI (d) & 97 & Adapted from Lam et al., 1997 \\
\hline \multicolumn{3}{|l|}{ Reproduction } \\
\hline Calving interval $(\mathrm{d})$ & 410 & CRV, 2017 \\
\hline Extra days open due to CM before 20 DIM & 25 & Santos et al., 2004 \\
\hline Extra days open due to subclinical IMI at calving & 49 & Pinedo et al., 2009 \\
\hline Cost of extra days open $(€ / d)$ & 2 & Adapted from Inchaisri et al., 2010 \\
\hline \multicolumn{3}{|l|}{ Culling } \\
\hline Probability of culling CM cows & 0.15 & van Soest et al., 2016 \\
\hline Probability of culling subclinical mastitis cows & 0.12 & Swinkels et al., 2005 \\
\hline Rearing costs $(€)$ & 1,567 & Mohd Nor et al., 2012 \\
\hline Slaughter value of a cow $(€)$ & 500 & Authors' expertise \\
\hline Life span of a cow $(y r)$ & 5 & Authors' expertise \\
\hline \multicolumn{3}{|l|}{ Labor } \\
\hline $\operatorname{Cost}(€ / \mathrm{h})$ & 24 & Blanken et al., 2018 \\
\hline \multicolumn{3}{|l|}{ Drying off } \\
\hline Gradually drying off (no. of days) & 7 & Authors' expertise \\
\hline Cost of cabergoline $(€)$ & 25 & Authors' expertise \\
\hline Labor for applying cabergoline (min) & 1.5 & Authors' expertise \\
\hline Labor for applying gradual milking $(\mathrm{min} / \mathrm{d})$ & 10 & Huijps et al., 2010 \\
\hline Labor for applying gradual feeding $(\mathrm{min} / \mathrm{d})$ & 20 & Huijps et al., 2010 \\
\hline Cost of gradual drying off (fences; $€ /$ cow) & 2 & Adapted from Huijps et al., 2010 \\
\hline \multicolumn{3}{|l|}{ Feed } \\
\hline $\operatorname{Cost}^{2}(€ / \mathrm{kVEM})$ & 0.16188 & Remmelink et al., 2017 \\
\hline
\end{tabular}

${ }^{1} \mathrm{CM}=$ clinical mastitis.

${ }^{2}$ Feed requirements estimated as energy requirements in feed units for lactation (VEM; 1 VEM $=1.65$ kcal of $\mathrm{NE}_{\mathrm{L}}$ ) as defined by van Es (1978).

at calving, and this IMI can be either subclinical or clinical. For subclinically infected cows, the duration of infection was determined using a pert distribution with a minimum of $1 \mathrm{~d}$, a most likely duration of $97 \mathrm{~d}$, and a maximum of the whole of lactation. Subclinically infected cows had a probability of having a clinical flareup, and the day of the clinical flare-up was determined using a uniform distribution with a minimum value of $d$ 1 of lactation, and a maximum value of the last day of the subclinical IMI period. For every clinical IMI case, it was determined using a discrete distribution whether the veterinarian will attend the cow using a probability of 0.05. It was assumed that every clinical IMI was treated with a 3-d antibiotic treatment, and that these cases can either cure completely, cure only clinically, or not be cured at all. Information on labor time and withdrawal period for milk for treated cases of clinical IMI is given in Table 2 .

Only completely noncured clinical IMI cases (bacteriologically and clinically) were culled immediately. All other clinical IMI cases had a probability to be culled, which was determined using a discrete probability distribution. The day of culling was determined using a uniform distribution from $5 \mathrm{~d}$ after the clinical IMI event until the last day of lactation. Also, cows with subclinical IMI had a probability to be culled. For cows with subclinical IMI, the day of culling was determined using a uniform distribution, with the first day of lactation as the minimum and the last day of infection as the maximum.

A distinction in milk production losses for clinical IMI was made between cases directly occurring at calving or flare-up cases later in lactation. Milk production losses due to subclinical IMI were modeled as a function of SCC. The SCC of a cow was described using a pert distribution. Minimum cow SCC for cows with subclinical mastitis was assumed to be 200,000 cells/mL. The most likely cow SCC was assumed to be $1,349,519$ cells $/ \mathrm{mL}$. This number was based on a single quarter infected with Streptococcus uberis and having a SCC of 5,248,075 cells/mL (Schepers et al., 1997) and 3 uninfected quarters with a SCC of 50,000 
cells/mL. Quarter milk can reach 13,000,000 cells/mL $\mathrm{mL}[(13,000,000+3 \times 50,000) / 4]$. The cow SCC was without clinical symptoms (Pyörälä and Mattila, 1987). determined for each day of the subclinical IMI period. Therefore, the maximum cow SCC was 3,287,500 cells/ The estimates for daily milk production losses were

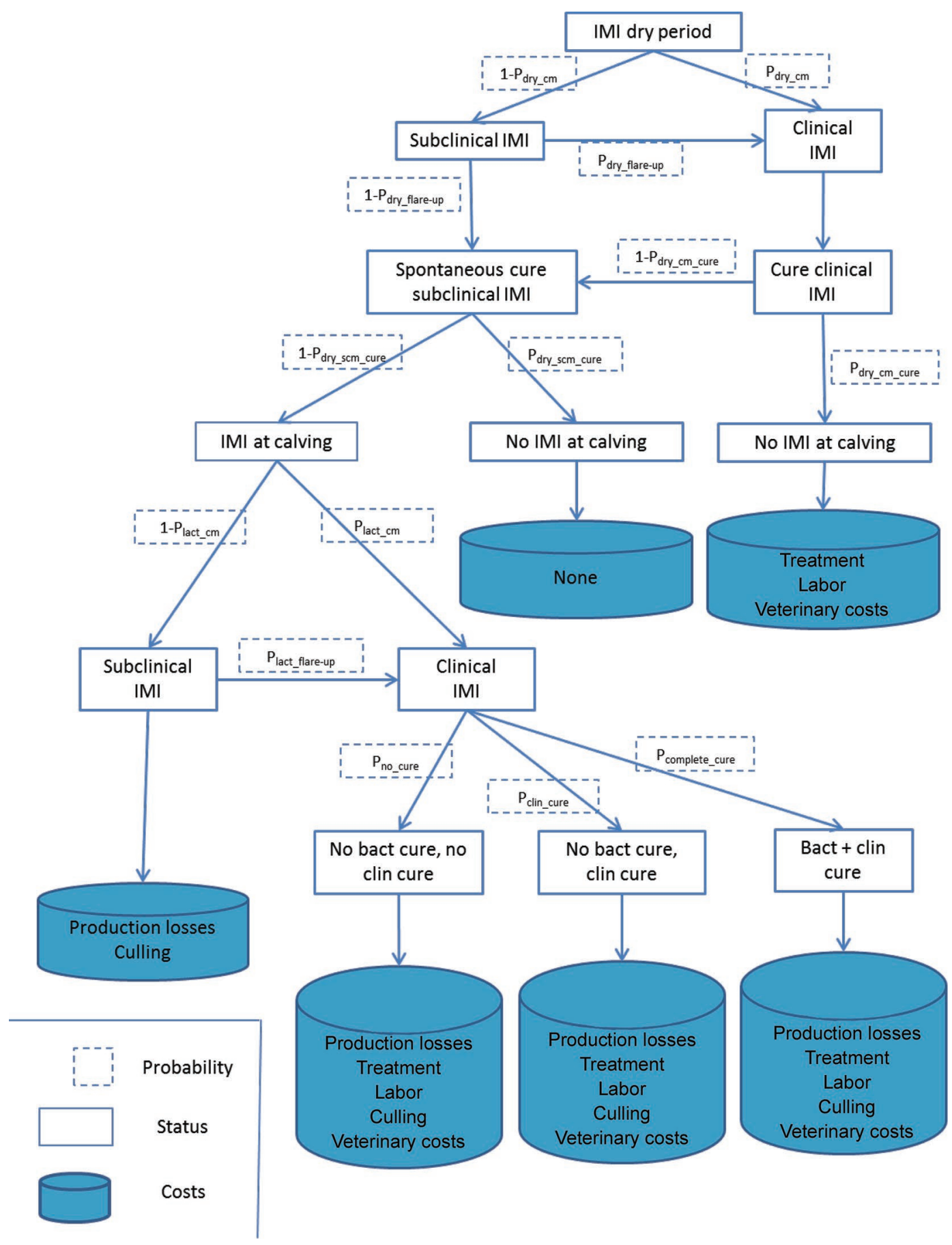

Figure 1. Schematic overview of the dynamics of infection for a cow having an IMI during the dry period. $\mathrm{P}_{\text {dry_cm }}=$ probability of IMI during dry period to be clinical; $\mathrm{P}_{\text {dry_flare-up }}=$ probability of clinical flare-up during the dry period; $\mathrm{P}_{\text {dry_cm_cure }}=$ probability of cure for clinical IMI during the dry period; $\mathrm{P}_{\text {dry_scm_cure }}=$ probability of spontaneous cure for subclinical IMI during the dry period; $\mathrm{P}_{\text {lact_cm }}=$ probability of IMI at calving to be clinical; $\mathrm{P}_{\text {lact flare-up }}=$ probability of clinical flare-up during lactation; $\mathrm{P}_{\text {complete cure }}=$ probability of bacteriological and clinical cure for clinical IMI; $\mathrm{P}_{\text {clin_cure }}=$ probability of no bacteriological and clinical cure for clinical IMI; $\mathrm{P}_{\text {no_cure }}=$ probability of no bacteriological and no clinical cure for clinical IMI; bact = bacteriological; clin = clinical. 
based on Hortet et al. (1999), and were dependent on cow SCC, parity (2 or $\geq 3)$, and DIM. Before the clinical flare-up, the milk production losses are equal to milk production losses due to subclinical IMI, and from the moment of the clinical flare-up onward, the milk production losses are equal to $5 \%$ for the rest of the lactation.

Cows that had a clinical IMI at calving, and cows that get a clinical flare-up before d 20 of lactation, have a 25-d longer calving interval (Santos et al., 2004). Cows that had a subclinical IMI at calving have a 49-d longer calving interval (Pinedo et al., 2009).

\section{Simulation of Different Methods of Drying Off}

For simulation of the different drying off methods European circumstances are assumed, which in most cases will include setting up fences for gradual cessation of lactation. For the gradual milking treatment, it was assumed that cows were milked only once a day for the last $7 \mathrm{~d}$ of lactation. Milk yield was reduced daily by $5,15,25,30$, and $40 \%$ for d 1 until $\geq 5$ for the gradual-milking treatment, respectively. Feed requirements were adjusted downward for the reduced milk yield. For the gradual-feeding treatment, it was assumed that cows get a dry-cow feed ration during the last $7 \mathrm{~d}$ of lactation with feed requirements of 10,000 VEM per day. Milk yield was reduced daily by 15,25 , 35,40 , and $50 \%$ for $\mathrm{d} 1$ until $\geq 5$ for the gradual-feeding treatment, respectively. For both gradual-feeding and gradual-milking treatments, it was assumed that cows were housed separately from the other milking cows, and costs of extra fences were assumed (Table 2). Also, extra labor time was assumed for housing the cows separately (Table 2). For applying CAB, it was assumed that farmers applied it during the last day of lactation. The CAB is applied only once, immediately after dry off. The product is sold as an injectable and can be stored at room temperature.

\section{Economic Calculations}

Milk revenues during the milk reduction period were calculated based on the milk yield of the last $7 \mathrm{~d}$ of lactation and the milk price. Feed costs during the milk reduction period were based on the total VEM in the last $7 \mathrm{~d}$ of lactation and the price of VEM. Costs for applying $\mathrm{CAB}$ included the costs for $\mathrm{CAB}$ and extra labor. Costs for the gradual-feeding and gradual-milking treatments included costs for labor and making fences. Cows that had a subclinical IMI during the dry period had no IMI costs during the dry period. Cows that had a clinical IMI during the dry period had costs for antibiotics, labor, and veterinary visits. The costs for a subclinical IMI during the lactation included costs for milk yield losses, culling, and a prolonged calving interval. The costs for a clinical IMI during lactation included costs for milk yield losses, treatment (antibiotics and milk withdrawal), labor, veterinary visits, a prolonged calving interval (only when clinical IMI cases occurred before $20 \mathrm{~d}$ after calving), and culling. Clinical IMI that are clinically cured but not bacteriologically cured had a risk of repeated clinical mastitis cases. To take this into account, the costs for antibiotics, milk withdrawal, labor, and veterinarian of these clinical IMI were multiplied by 1.5 . Clinical cured IMI cases that are not bacteriologically cured are subclinical IMI and had costs for milk yield losses and culling.

Cows that were culled before the end of parity 5 were assumed to be culled too early, resulting in extra costs for rearing extra heifers (Mostert et al., 2018). The culling costs were based on the price of purchasing a new heifer and the revenues gained from selling the cow for slaughter. In addition to these, the loss of future returns from the culled cow was taken into account. First, the difference between the rearing costs of a new heifer and the slaughter value was determined. Subsequently, this difference was depreciated over the life span of the cow ( $5 \mathrm{yr})$. The culling costs are the number of missed lactations multiplied by the depreciated value (Getaneh et al., 2017).

The net costs for the 3 dry-off methods were calculated as the sum of costs (feed, labor, and IMI costs during the dry period, IMI costs during lactation, and other costs (CAB and fences), minus the milk revenues.

\section{Validation and Sensitivity Analyses}

Because data for external validation of the model were not available, an internal validation was performed. A large number of inputs (e.g., probability of ML and probability of IMI) were compared with the output (e.g., number of cows with ML, number of cows with IMI during and after dry period) to check the consistency and credibility of the model output.

Sensitivity analyses were conducted to verify the values of the input parameters. The results of the sensitivity analyses on each parameter were compared with the results of the model outcome in the default situation to assess the effect of each parameter on the marginal economic effect. When sensitivity analyses were carried out on one parameter, the other parameters were retained at default values. Sensitivity analyses were performed for the probability of IMI during the dry period without ML, odds ratio of getting IMI with ML, the percentage reduction in $\mathrm{ML}$ when using $\mathrm{CAB}$, the 
number of days for gradually drying off, labor time for gradual milking, and the average 305 -d milk production of the herd.

\section{RESULTS}

Biological output for the 3 dry-off methods is presented in Table 3. Abrupt-CAB cows gave, on average, $20.8 \mathrm{~kg} / \mathrm{d}$ of milk at drying off, and $90 \%$ (5 to 95 percentiles) of the cows had a milk yield at drying off between 17.6 and $24.3 \mathrm{~kg} / \mathrm{d}$. Using gradual-milking and gradual-feeding methods, the average milk yield at drying off was 12.5 and $10.4 \mathrm{~kg} / \mathrm{d}$, respectively. With abrupt CAB, $5.7 \%$ of the cows had ML compared with 19.7 and $14.7 \%$ of the gradual-milking and gradualfeeding cows, respectively. With abrupt CAB, 25.8\% of the cows had an IMI in the dry period, compared with 29.6 and $28.3 \%$ of the gradual-milking and gradual-feeding cows, respectively. The percentage of cows having an IMI at calving was 20.5, 23.2, and $22.0 \%$ for the abrupt-CAB, gradual-milking, and gradual-feeding treatments, respectively.

The average net cost of the abrupt-CAB method, as presented in Table 4, was €49.6/cow. This number included feed costs during the gradual period ( $€ 18.6 /$ cow), labor costs (€0.6/cow), IMI costs during the dry period and lactation ( $€ 1.1$ and $€ 56.0 /$ cow $)$, cost of $\mathrm{CAB}$ (€25/cow), and milk returns (€51.7/cow). The average IMI costs during lactation (€56.0/cow) included costs for medicines (€3.0/cow), labor $(€ 2.5 / \mathrm{cow})$, veterinarian (€0.1/cow), production losses (€37.1/cow), milk withdrawal (€8.7/cow), culling (€9.9/cow), reproduction (€14.4/cow), and reduced feed costs (€19.7/cow). Compared with abrupt $\mathrm{CAB}$, gradual feeding and gradual milking resulted in lower milk returns, lower feed costs, higher labor costs, higher IMI costs during lactation, and lower costs for fences. Overall, abrupt $\mathrm{CAB}$ resulted in the lowest average net cost (€49.6/ cow) compared with gradual feeding (€99.1/cow) and gradual milking ( $€ 71.5 / \mathrm{cow})$. In total, $90 \%$ of the net costs for gradual feeding are between $€ 32.3$ and $€ 359.5 /$ cow. For abrupt CAB, $90 \%$ of the net costs are between $-€ 13.7$ and $€ 307.8 / \mathrm{cow}$. The negative net costs $(-€ 13.7)$ means that for some cows the benefits (milk revenues) are higher than all the costs (feed, labor, IMI, and $\mathrm{CAB}$ ).

Results of the sensitivity analyses are presented in Table 5. A higher probability of IMI during the dry period without ML (0.4 instead of 0.24 ) resulted in higher average net costs for the 3 dry-off methods. Also, a higher odds ratio (3 instead of 2.2) for having IMI with ML resulted in higher average net costs for the 3 dry-off methods. Assuming 2 and $5 \mathrm{~min} / \mathrm{d}$ labor for gradual milking resulted in average net costs of $€ 49.2$ and $€ 59.9$ per cow, respectively.

\section{DISCUSSION}

Abrupt cessation of milking has several disadvantages. It has been proven to increase the risk of new IMI due to milk accumulation and ML (RajalaSchultz et al., 2005; Silanikove et al., 2013; Zobel et al., 2013) and it has been associated with distress and with considerable engorgement of the mammary gland, resulting in udder discomfort and pain (O'Driscoll et al., 2011; Silanikove et al., 2013). In this paper, for 3 alternatives to dry-off cows (gradual feeding, gradual milking, and abrupt CAB), the net costs attributable to each cessation of milk method were calculated. A stochastic model simulated cows over 2 lactations and factored in all the relevant costs and revenues that would vary by dry-off method. The model produced meaningful calculations regarding the economics of 3 different dry-off methods. The abrupt-CAB method resulted in the lowest average net costs $€ 49.6 /$ cow. By using $\mathrm{CAB}$, on average $€ 49.5 /$ cow and $€ 21.9 /$ cow were saved compared with the gradual-feeding and gradualmilking methods, respectively. The differences between the dry-off methods were mainly due to differences in milk returns, labor costs, and other costs (e.g., CAB).

Table 3. Average biological output ( 5 and 95 percentiles within parentheses) of 3 different methods of drying off: gradual feed reduction (gradual feeding), gradual milking frequency reduction (gradual milking), and abrupt cessation of milking with cabergoline (abrupt CAB) ${ }^{1}$

\begin{tabular}{lccc}
\hline Item & Gradual feeding & Gradual milking & Abrupt CAB \\
\hline Milk production at dry off $(\mathrm{kg} / \mathrm{d})$ & 10.8 & 12.6 & 20.8 \\
& $(8.8 ; 12.1)$ & $(10.6 ; 14.6)$ & $(17.6 ; 24.3)$ \\
Total milk production 7 d before dry off $(\mathrm{kg})$ & 92 & 107 & 148 \\
& $(77 ; 107)$ & $(90 ; 124)$ & $(124 ; 172)$ \\
Cows leaking milk (\%) & 14.7 & 19.7 & 5.7 \\
Cows with IMI in dry period (\%) & 28.3 & 29.6 & 25.8 \\
Cows with IMI at calving (\%) & 22.0 & 23.2 & 20.5 \\
Cows with CM at or after calving (\%) & 14.1 & 14.5 & 12.6 \\
Cows with SCM at calving (\%) & 7.9 & 8.7 & 7.9 \\
\hline
\end{tabular}

${ }^{1} \mathrm{CM}=$ clinical mastitis; $\mathrm{SCM}=$ subclinical mastitis. 
Table 4. Average net costs $(€ /$ cow) for gradual feed reduction (gradual feeding), gradual milking frequency reduction (gradual milking), and abrupt cessation of milking with cabergoline (abrupt CAB; 5, 50, and 95 percentiles within parentheses)

\begin{tabular}{lccc}
\hline Item & Gradual feeding & Gradual milking & Abrupt CAB \\
\hline Milk before dry off & 32.2 & 37.4 & 51.7 \\
& $(27.0 ; 32.1 ; 37.4)$ & $(31.5 ; 36.9 ; 43.5)$ & $(43.4 ; 51.7 ; 60.2)$ \\
Feed at gradual period & 11.3 & 15.4 & 18.6 \\
& & $(13.9 ; 15.2 ; 16.9)$ & $(16.6 ; 18.6 ; 20.7)$ \\
Labor at drying off & 56 & 28 & 0.6 \\
IMI in dry period & 1.3 & 1.3 & 1.1 \\
& $(0 ; 0 ; 0)$ & 62.2 & $(0 ; 0 ; 0)$ \\
IMI at new lactation & 60.7 & $(0 ; 0 ; 502.8)$ & $(0 ; 0 ; 494.8)$ \\
& $(0 ; 0 ; 497.2)$ & 3.5 & 3 \\
Medicines & 3.4 & 2.9 & 2.5 \\
Labor & 2.8 & 0.2 & 0.1 \\
Veterinarian & 0.2 & 42.8 & 37.1 \\
Production losses & 41.2 & 10.1 & 9.7 \\
Milk withdrawal & 9.7 & 11.1 & 14.4 \\
Culling & 10.0 & 16.2 & 19.7 \\
Reproduction & 15.2 & 22.6 & 25 \\
Reduced feed costs & 21.8 & 2 & 49.6 \\
Other costs (cabergoline, fences) & 2 & 71.5 & $(-13.7 ;-5.9 ; 307.8)$ \\
Net costs & 99.1 & $(3.8 ; 9.4 ; 347.3)$ & \\
& $(32.3 ; 38.6 ; 359.5)$ & & \\
\hline
\end{tabular}

The costs of IMI contributed the most to the average net costs of the dry-off method, but the differences in these costs were small between the 3 methods (Table 4 ), due to the small differences in occurrence of IMI at calving $(20.5,23.2$, and $22.0 \%$; Table 3 ).

The method of dry off influences ML, and the use of CAB reduces ML (Bach et al., 2015; Bertulat et al., 2017). Because ML is a risk factor for IMI (Schukken et al., 1993), we included IMI during the dry period and during lactation as a factor when calculating the net costs of the dry-off method. It was, for the purpose of the present study, assumed that ML is the only mechanism through which IMI can occur in the dry period and, therefore, cause IMI at calving. Thus, it was assumed that only the differences in ML between the 3 dry-off methods were causing differences in IMI occurrence during the dry period and subsequent lactation. However, existing infections at dry off (and a high SCC at the last test-day) may have an influence on the IMI during the dry period and at calving (Halasa et al., 2009b), but we ignored these because an assumption in the model was that these IMI did not influence the net costs across the 3 dry-off methods. Because new IMI were acquired during the dry period, we also assumed that new IMI are only caused by environmental pathogens. Also, SCC of subclinical IMI after calving were modeled based on SCC of environmental pathogens (Schepers et al., 1997). The SCC on any given day was modeled independently of the SCC of the previous day as no studies were found quantifying those dependen-

Table 5 . Sensitivity of the average net costs $(€ /$ cow) for gradual feed reduction (gradual feeding), gradual milking frequency reduction (gradual milking), and abrupt cessation of milking with cabergoline (abrupt CAB) ${ }^{1}$

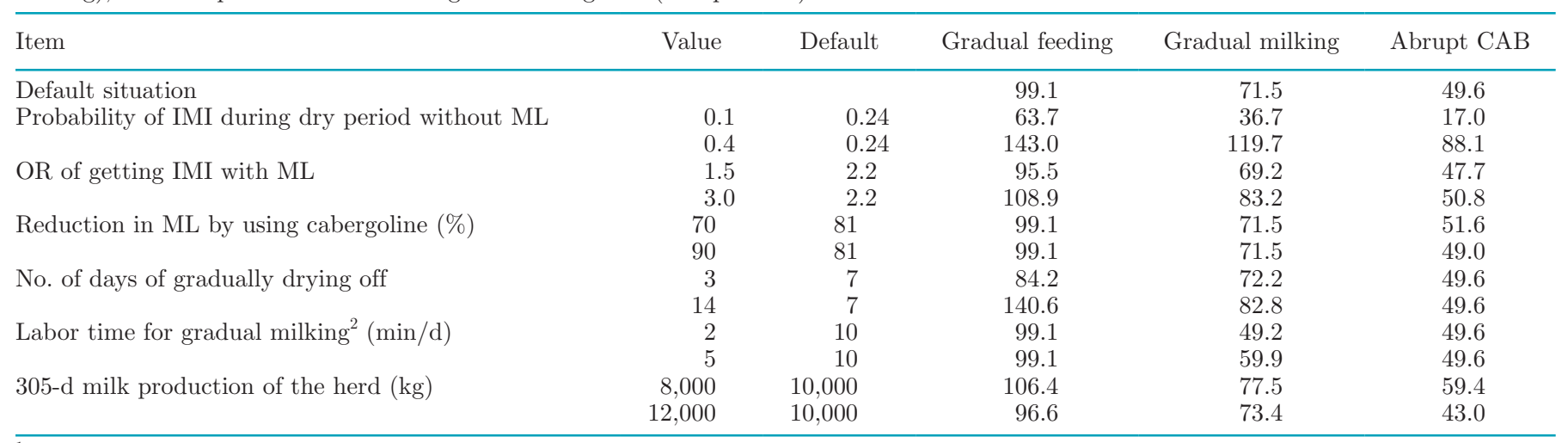

${ }^{1} \mathrm{OR}=$ odds ratio; $\mathrm{ML}=$ milk leakage.

${ }^{2}$ Also, no costs for fences $(€ 2 /$ cow $)$ assumed. 
cies. Including a dependency based on authors' expertise resulted in approximately the same results (results not shown) for milk production losses (<€1 difference) as with the approach without any dependency.

To model the occurrence of ML across the 3 dry-off methods, detailed input values were needed that were not always available in the literature. However, some output values were available. For example, it is known that the difference in the probability of IMI at calving between abrupt cessation of milk and abrupt cessation of milk coupled with CAB is $21 \%$ (EU/2/15/192/001004; EMA, 2015). Because of the mechanistic nature of the simulation model, we could not use this as an input value, and therefore the available knowledge from research was combined with the authors' expertise to calibrate some input values (Table 1) so that the output of the model equated to $21 \%$ for all 3 dry-off methods. When IMI occurred, the dynamics of infection were modeled (Figure 1), and this modeling approach is similar to previously described models for the dynamics of infection (e.g., Halasa et al., 2009a).

It is expected that CAB will be part of a herd management program designed by the veterinarian and farmer. In many cases CAB will be applied to all cows to simplify the dry-off management procedure to make it similar for all cows and to reduce the welfare issues at dry-off. It will be very interesting to know for which cows $\mathrm{CAB}$ would be profitable and for which cows it would not be profitable. The aim of the current study, however, was not to determine for which specific cows $\mathrm{CAB}$ would be profitable. Such a question asks for another model (tool) in which additional cow- and herd-specific input values have to be entered (e.g., milk production at dry off, parity, labor costs, and so on).

Because of these uncertainties regarding input values for the occurrence of ML and IMI, various sensitivity analyses were performed. Results showed that for farms with more IMI, applying CAB becomes relatively more beneficial as the difference in net costs with the gradual dry-off methods becomes higher. But even for farms with very few IMI at calving, abrupt $\mathrm{CAB}$ resulted in the lowest average net costs in comparison with the gradual dry-off methods. The results also showed that labor costs had a large influence on the net costs of the 3 dry-off methods. In the default model, labor costs were assumed for gradual feeding and gradual milking (€28 and €56/cow, Table 4). These labor cost results are very realistic for dairy farms as the gradual cow approach requires several different additional actions (e.g., changing pens, separate feeding, separate milking, and so on) from the farmer. In other farming systems gradual milking can probably be applied differently, resulting in a lower labor demand. Specifically, in automatic milking systems limited time will be necessary to program the cows for only once a day milking. To illustrate these farming systems, assuming 2 and $5 \mathrm{~min} / \mathrm{d}$ time for gradual milking was included in the sensitivity analysis. Results show that assuming 2 and $5 \mathrm{~min} / \mathrm{d}$ for gradual milking resulted in average net cost of $€ 49.2$ and $€ 59.9$ per cow.

Gradual dry-off methods and using abrupt CAB also have some nontangible advantages over the abrupt cessation of milk (i.e., without CAB), but these advantages are not included in the model because it is difficult to connect an economic value to them. For example, the long-term effects of reducing the need for the use of antimicrobials at dry off have not been considered. For decades, the use of dry-cow antibiotics has been one of the key points recommended within the "five-point plan" to cure existing infections and to prevent new IMI from developing during the dry period (Neave et al., 1966). However, preventive use of antibiotics in food animals has led to realistic concerns about its potential contribution to the rising levels of antimicrobial resistance in both humans and animals. This issue has propagated a movement toward prudent and more restricted use of antibiotics at dry off, especially in some Northern European countries where preventive use is no longer allowed (Scherpenzeel et al., 2014). Therefore, infected cows first need to be identified based on various criteria (level of SCC, bacteriological culture, clinical mastitis history, or combinations of these criteria) to treat them with antibiotics at dry off. For the noninfected cows, which are not treated with $\mathrm{AB}$ at dry off, the risk of acquiring new IMI may increase, as it was found that quarters from cows with a low SCC with no antibiotic treatment at dry off had a 1.7-times higher incidence rate of clinical mastitis during the dry period and the first $100 \mathrm{~d}$ in the subsequent lactation than in quarters dried off with antibiotics (Scherpenzeel et al., 2014). Thus, the use of nonantibiotic tools such as CAB may play an important role in these situations.

Another nontangible advantage of the use of abrupt $\mathrm{CAB}$, which was not taken into account in our model, concerns cow welfare. It was reported that cows treated with $\mathrm{CAB}$ lay down for significantly more time during the first day after dry off compared with controls, and that udder pressure and signs of pain were significantly reduced (Bach et al., 2015; Bertulat et al., 2017). With regard to gradual feeding, there are concerns related to cow welfare (Valizaheh et al., 2008). Cows on restricted feed before dry off experience greater blood fatty acid and cortisol levels (which may lead to metabolic problems) compared with cows with no imposed feed restriction (Odensten et al., 2005, 2007b). In addition, cows undergoing nutrient restriction vocalize more than cows offered unrestricted access to feed and this vocalization may be an indicator of hunger (Tucker et al., 2009). 


\section{CONCLUSIONS}

Under default conditions in our simulation model, the average net costs of applying $\mathrm{CAB}$ in conjunction with the abrupt cessation of milking was $€ 49.6 /$ cow. This number included feed costs (during the last $7 \mathrm{~d}$ of lactation), labor costs, IMI costs during dry period and during lactation, costs for $\mathrm{CAB}$ and milk returns (during the last $7 \mathrm{~d}$ of lactation). Results showed that $90 \%$ of the net costs will vary between - €13.7 and €307.8/ cow. In contrast, the average net costs of applying the gradual-feeding and gradual-milking approaches to dry off were significantly higher, at €99.1 and €71.5/cow, respectively. Overall, in comparison to applying the abrupt-CAB method, the gradual-feeding and gradualmilking methods resulted in lower milk returns, lower feed costs, higher labor costs, higher IMI costs during lactation, and lower other costs. Thus, as part of an abrupt cessation of milking approach, $\mathrm{CAB}$ saved an average of $€ 49.5$ and $€ 21.9 /$ cow compared with gradual feed reduction and gradual-milking frequency reduction dry-off methods, respectively.

\section{ACKNOWLEDGMENTS}

The authors thank Alex Bach (ICREA, Catalan Institution for Research and Advanced Studies, Barcelona, Spain) and Ynte Schukken (GD Animal Health, Deventer, the Netherlands) for helpful discussions.

\section{REFERENCES}

Annen, E. L., R. J. Collier, M. A. McGuire, J. L. Vicini, J. M. Ballam, and M. J. Lormore. 2004. Effect of modified dry period lengths and bovine somatotropin on yield and composition of milk from dairy cows. J. Dairy Sci. 87:3746-3761.

Bach, A., A. De-Prado, and A. Aris. 2015. Short communication: The effects of cabergoline administration at dry-off of lactating cows on udder engorgement, milk leakages, and lying behavior. J. Dairy Sci. 98:7097-7101.

Bertulat, S., C. Fischer-Tenhagen, and W. Heuwieser. 2015. A survey of drying-off practices on commercial dairy farms in northern Germany and a comparison to science-based recommendations. Vet. Rec. Open 2:e00068.

Bertulat, S., C. Fischer-Tenhagen, V. Suthar, E. Möstl, N. Isaka, and W. Heuwieser. 2013. Measurement of fecal glucocorticoid metabolites and evaluation of udder characteristics to estimate stress after sudden dry-off in dairy cows with different milk yields. J. Dairy Sci. 96:3774-3787.

Bertulat, S., N. Isaka, A. de Prado, A. Lopez, T. Hetreau, and W. Heuwieser. 2017. Effect of a single injection of cabergoline at dry off on udder characteristics in high-yielding dairy cows. J. Dairy Sci. 100:3220-3232.

Blanken, K., F. de Buisonje, A. Evers, W. Ouweltjes, H. Holster, J. Verkaik, I. Vermeij, and H. Wemmenhove. 2018. Handboek Kwantitatieve Informatie Veehouderij, KWIN-V 2018-2019, Handboek 36 (Quantitative Information Livestock Farming 2018-2019, Handbook 36). Wageningen Livestock Research, Wageningen UR, Wageningen, the Netherlands.

Boutinaud, M., N. Isaka, E. Gandemer, P. Lamberton, S. Wiart, A. I. De Prado Taranilla, L. M. Sordillo, and V. Lollivier. 2017. In- hibiting prolactin by cabergoline accelerates mammary gland remodeling during the early dry period in dairy cows. J. Dairy Sci. 100:9787-9798.

Boutinaud, M., N. Isaka, V. Lollivier, F. Dessauge, E. Gandemer, P. Lamberton, A. I. De Prado Taranilla, A. Deflandre, and L. M. Sordillo. 2016. Cabergoline inhibits prolactin secretion and accelerates involution in dairy cows after dry-off. J. Dairy Sci. 99:5707-5718.

Chapinal, N., G. Zobel, K. Painter, and K. E. Leslie. 2014. Changes in lying behavior after abrupt cessation of milking and regrouping at dry-off in freestall-housed cows: A case study. J. Vet. Behav. Clin. Appl. Res. 9:364-369.

CRV. 2017. Annual report 2017. CRV (cattle breeding company), Arnhem, the Netherlands.

Dingwell, R., K. Leslie, L. L. Timms, and J. Sargent. 2004. Association of cow and quarter level factors at dry off and new intramammary infections in the dry period. Prev. Vet. Med. 63:75-89.

EMA. 2015. Velactis EPAR summary. Accessed Oct. 23, 2018. https:// www.ema.europa.eu/documents/overview/velactis-epar-summary -public_en.pdf.

Getaneh, A. M., S. A. Mekonnen, and H. Hogeveen. 2017. Stochastic bio-economic modeling of mastitis in Ethiopian dairy farms. Prev. Vet. Med. 138:94-103.

Gott, P. N., P. J. Rajala-Schultz, G. M. Schuenemann, K. L. Proudfoot, and J. S. Hogan. 2016. Intramammary infections and milk leakage following gradual or abrupt cessation of milking. J. Dairy Sci. 99:4005-4017.

Halasa, T., M. Nielen, R. B. M. Huirne, and H. Hogeveen. 2009a. Stochastic bio-economic model of bovine intramammary infection. Livest. Sci. 124:295-305.

Halasa, T., M. Nielen, A. C. Whist, and O. Osteras. 2009b. Metaanalysis of dry cow management for dairy cattle. Part 2. Cure of existing intramammary infections. J. Dairy Sci. 92:3150-3157.

Hortet, P., F. Beaudeau, H. Seegers, and C. Fourichon. 1999. Reduction in milk yield associated with somatic cell counts up to 600,000 cells $/ \mathrm{ml}$ in French Holstein cows without clinical mastitis. Livest. Prod. Sci. 61:33-42.

Huijps, K., H. Hogeveen, T. Lam, and A. Oude Lansink. 2010. Costs and efficacy of management measures to improve udder health on Dutch dairy farms. J. Dairy Sci. 93:115-124.

Huijps, K., T. Lam, and H. Hogeveen. 2008. Costs of mastitis: Facts and perception. J. Dairy Res. 75:113-120.

Inchaisri, C., R. Jorritsma, P. Vos, G. C. van der Weijden, and H. Hogeveen. 2010. Economic consequences of reproductive performance in dairy cattle. Theriogenology 74:835-846.

Klaas, I. C., C. Enevoldsen, A. K. Ersboll, and U. Tolle. 2005. Cowrelated risk factors for milk leakage. J. Dairy Sci. 88:128-136.

Lacasse, P., S. Ollier, V. Lollivier, and M. Boutinaud. 2016. New insights into the importance of prolactin in dairy ruminants. J. Dairy Sci. 99:864-874.

Lam, T. J. G. M., J. H. van Vliet, Y. H. Schukken, F. J. Grommers, A. van Velden-Russcher, H. W. Barkema, and A. Brand. 1997. The effect of discontinuation of postmilking teat disinfection in low somatic cell count herds. II. Dynamics of intramammary infections. Vet. Q. 19:47-53.

Mohd Nor, N., W. Steeneveld, M. C. M. Mourits, and H. Hogeveen. 2012. Estimating the costs of rearing young dairy cattle in the Netherlands using a simulation model that accounts for uncertainty related to diseases. Prev. Vet. Med. 106:214-224.

Mostert, P. F., E. A. M. Bokkers, C. E. van Middelaar, H. Hogeveen, and I. J. M. de Boer. 2018. Estimating the economic impact of subclinical ketosis in dairy cattle using a dynamic stochastic simulation model. Animal 12:145-154.

Natzke, R. P., R. W. Everett, and D. R. Bray. 1975. Effect of drying off practices on mastitis infection. J. Dairy Sci. 58:1828-1835.

Neave, F. K., F. H. Dodd, and R. G. Kingwill. 1966. A method of controlling udder disease. Vet. Rec. 78:521-523.

NMC (National Mastitis Council). 2006. NMC Factsheet - Dry Cow Therapy. National Mastitis Council, New Prague, MN.

O'Driscoll, K., D. Gleeson, B. O'Brien, and L. Boyle. 2011. Does omission of a regular milking event affect cow comfort? Livest. Sci. 138:132-143. 
Odensten, M. O., B. Berglund, K. P. Waller, and K. Holtenius. 2007a. Metabolism and udder health at dry-off in cows of different breeds and production levels. J. Dairy Sci. 90:1417-1428.

Odensten, M. O., Y. Chilliard, and K. Holtenius. 2005. Effects of two different feeding strategies during dry-off on metabolism in highyielding dairy cows. J. Dairy Sci. 88:2072-2082.

Odensten, M. O., K. Holtenius, and K. P. Waller. 2007b. Effects of two different feeding strategies during dry-off on certain health aspects of dairy cows. J. Dairy Sci. 90:898-907.

Pinedo, P. J., P. Melendez, J. A. Villagomez-Cortes, and C. A. Risco. 2009. Effect of high somatic cell counts on reproductive performance of Chilean dairy cattle. J. Dairy Sci. 92:1575-1580.

Pyörälä, S., and T. Mattila. 1987. Inflammatory changes during experimental bovine mastitis induced by Staphylococcus aureus, Streptococcus dysgalactiae and Streptococcus uberis. J. Vet. Med. A Physiol. Pathol. Clin. Med. 34:574-581.

Rajala-Schultz, P. J., J. S. Hogan, and K. L. Smith. 2005. Short communication: Association between milk yield at dry-off and probability of intramammary infections at calving. J. Dairy Sci. 88:577-579.

Remmelink, G. J., K. Blanken, J. C. van Middelkoop, W. Ouweltjes, and H. Wemmenhove. 2017. Handboek Melkveehouderij 2017/2018 (Handbook of Dairy Farming). Wageningen Livestock Research, Wageningen UR, Wageningen, the Netherlands.

Santos, J. E. P., R. L. A. Cerri, M. A. Ballou, G. E. Higginbotham, and J. H. Kirk. 2004. Effect of timing of first clinical mastitis occurrence on lactational and reproductive performance of Holstein dairy cows. Anim. Reprod. Sci. 80:31-45.

Schepers, A. J., T. J. G. M. Lam, Y. H. Schukken, J. B. M. Wilmink, and W. J. A. Hanekamp. 1997. Estimation of variance components for somatic cell counts to determine thresholds for uninfected quarters. J. Dairy Sci. 80:1833-1840.

Scherpenzeel, C. G. M., I. E. M. den Uijl, G. van Schaik, R. G. M. Olde Riekerink, J. M. Keurentjes, and T. J. G. M. Lam. 2014. Evaluation of the use of dry cow antibiotics in low somatic cell count cows. J. Dairy Sci. 97:3606-3614.

Schukken, Y. H., J. Vanvliet, D. Vandegeer, and F. J. Grommers. 1993. A randomized blind trial on dry cow antibiotic infusion in a low somatic cell count herd. J. Dairy Sci. 76:2925-2930.
Silanikove, N., U. Merin, F. Shapiro, and G. Leitner. 2013. Early mammary gland metabolic and immune responses during natural-like and forceful drying-off in high-yielding dairy cows. J. Dairy Sci. 96:6400-6411.

Steeneveld, W., Y. H. Schukken, A. T. M. van Knegsel, and H. Hogeveen. 2013. Effect of different dry period lengths on milk production and somatic cell count in subsequent lactations in commercial Dutch dairy herds. J. Dairy Sci. 96:2988-3001.

Steeneveld, W., T. van Werven, H. W. Barkema, and H. Hogeveen. 2011. Cow-specific treatment of clinical mastitis: An economic approach. J. Dairy Sci. 94:174-188.

Swinkels, J. M., H. Hogeveen, and R. N. Zadoks. 2005. A partial budget model to estimate economic benefits of lactational treatment of subclinical Staphylococcus aureus mastitis. J. Dairy Sci. 88:4273-4287.

Tucker, C. B., S. J. Lacy-Hulbert, and J. R. Webster. 2009. Effect of milking frequency and feeding level before and after dry off on dairy cattle behavior and udder characteristics. J. Dairy Sci. 92:3194-3203.

Valizaheh, R., D. M. Veira, and M. A. G. von Keyserlingk. 2008. Behavioural responses by dairy cows provided two hays of contrasting quality at dry-off. Appl. Anim. Behav. Sci. 109:190-200.

van Es, A. J. H. 1978. Feed evaluation for ruminants. I. The systems in use from May 1977-onwards in The Netherlands. Livest. Prod. Sci. 5:331-345.

van Soest, F. J. S., I. M. G. A. Santman-Berends, T. J. G. M. Lam, and H. Hogeveen. 2016. Failure and preventive costs of mastitis on Dutch dairy farms. J. Dairy Sci. 99:8365-8374.

Vilar, M. J., M. Hovinen, H. Simojoki, and P. J. Rajala-Schultz. 2018. Short communication: Drying-off practices and use of dry cow therapy in Finnish dairy herds. J. Dairy Sci. 101:7487-7493.

Wood, P. D. P. 1967. Algebraic model of the lactation curve in cattle. Nature 216:164-165.

Zobel, G., K. Leslie, D. M. Weary, and M. A. G. von Keyserlingk. 2013. Gradual cessation of milking reduces milk leakage and motivation to be milked in dairy cows at dry-off. J. Dairy Sci. 96:5064-5071.

Zobel, G., D. M. Weary, K. E. Leslie, and M. A. G. von Keyserlingk. 2015. Invited review: Cessation of lactation: Effects on animal welfare. J. Dairy Sci. 98:8263-8277. 